\title{
ISLANDZKA DZIESIEECINA W ŚWIETLE TEORII GRUP INTERESU
}

\author{
Włodzimierz Gogłoza \\ http://orcid.org/0000-0002-0931-7413 \\ Uniwersytet Marii Curie-Skłodowskiej w Lublinie
}

\section{ABSTRACT}

\section{AN INTEREST-GROUP THEORY OF THE ICELANDIC TITHE}

Iceland was the first Nordic country which introduced mandatory tithe. According to the medieval authors the swift introduction of the church tax in Iceland was a result of an extraordinary deference Icelanders showed towards the bishop Gissur Ísleifsson. Contemporary scholars, on the other hand, point to the unusual structure of the church tax itself as the reason behind the acceptance of tithe by Icelanders. The Icelandic tithe was divided into four parts, two of which were collected by the wealthy owners of private churches. Therefore, some scholars argue, the tithe law of 1097 favored the most powerful members of society, who could impose their will on others without facing significant resistance. The aim of this article is to analyze the introduction of tithe in Iceland using the basic tools of the Public Choice School of economics - the interest group theory, and the free rider theory.

Keywords: tithe, medieval Iceland, public choice theory, interest group theory.

Słowa kluczowe: dziesięcina, średniowieczna Islandia, teoria publicznego wyboru, teoria grup interesu.

I. Uchwalenie około 1097 roku na Islandii obowiązkowej dziesięciny (tíund) było czymś wyjątkowym w krajach kręgu kultury skandynawskiej i należy je uznać za istotne wydarzenie w historii społeczności zamieszkującej tę wysuniętą daleko na północ wyspę. Pobór wspomnianej daniny stał się bodźcem do instytucjonalizacji islandzkiego Kościoła, w nieodległej przyszłości mającego odgrywać przemożną rolę na lokalnej scenie ,politycznej”. To dzięki dziesięcinie islandzcy wodzowie (goðar) zyskali pierwsze stałe źródło dochodów, a tworzenie się systemu parafialnego na obszarze, na którym ją pobierano, przyczyniło się do terytorializacji ich strefy wpływów. Proces ten doprowadził w dłuższej perspektywie do zmiany relacji między 
wodzami a wolnymi gospodarzami z umownej na administracyjno-prawną, stanowiąc tym samym katalizator procesów państwotwórczych¹.

Celem niniejszego artykułu jest analiza ukonstytuowania tíund z użyciem podstawowego narzędzia ekonomii publicznego wyboru (public choice economics) - teorii grup interesu. Zamierzam wykazać, że szeroko akceptowane w literaturze przedmiotu hipotezy dotyczące przyczyn zaskakująco sprawnego (na tle innych krajów nordyckich) wprowadzenia dziesięciny na Islandii są problematyczne, oraz sformułować alternatywne wyjaśnienie jej przyjęcia, uwzględniające nie tylko korzyści, jakie jej pobór mógł przynieść islandzkim elitom społecznym, ale także koszty, jakie musiały one ponieść, dążąc do realizacji swych celów.

II. Zgodnie z przekazem Ariego Fróði Porgilssona, utrwalonym na kartach Íslendingabók (XII-wiecznej kroniki uznawanej za relatywnie najbardziej wiarygodne staroislandzkie źródło narracyjne $)^{2}$, za czasów posługi biskupiej Gissura Ísleifssona, z jego inicjatywy, a przy poparciu wielkiego uczonego Sæmundra Sigfússona i pod kierunkiem głosiciela prawa Markúsa Skeggjasona, na Islandii zostało wprowadzone nowe prawo nakazujące wszystkim mieszkańcom publiczne wyszczególnienie całego swojego majątku, określenie pod przysięgą jego wartości i odprowadzenie dziesięciny w stosownej wysokości ${ }^{3}$. Autorzy islandzkich annałów datują to wydarzenie na rok $1097^{4}$. Nie była to pierwsza inicjatywa tego typu w krajach nordyckich, żadna wcześniejsza nie zakończyła się jednak powodzeniem, a i późniejsze przez wiele dziesięcioleci napotykały liczne trudności podczas prób wprowadzenia ich w życie.

W świetle zachowanych źródeł pierwsza taka próba została podjęta w latach 80. XI wieku przez duńskiego władcę Kanuta IV i stała się przyczyną rebelii prowadzącej do zgładzenia króla, przez co faktycznie zaczęto ją egzekwować w Danii dopiero w 1135 roku. W Norwegii do jej wprowadzenia miał się publicznie zobowiązać w 1110 roku Sigurðr I Jórsalafari (Krzyżowiec), lecz pierwsze niebudzące wątpliwości świadectwa dotyczące jej faktycznego poboru pojawiają się dopiero po 1163 roku, za panowania Magnúsa Erlingssona. W Szwecji udało się ją wprowadzić jeszcze później, gdyż dopiero pod koniec XII wieku. W czasach gdy Ari Fróði

1 Ogólnie na temat islandzkiej dziesięciny i konsekwencji jej uchwalenia zob. w: O. Vesteinsson, The Christianization of Iceland: Priests, Power, and Social Change 1000-1300, Oxford 2000, s. 67-92; J. Jóhannesson, Íslendinga Saga: A History of the Old Icelandic Commonwealth, Winnipeg 1974, s. 170-178; B.T. Runolfsson Solvason, Institutional Evolution in the Icelandic Commonwealth, „Constitutional Political Economy” 1993, vol. 4, no. 1, s. 115-122.

$2 \mathrm{Na}$ temat tej kroniki, jej autora i kwestii historycznej wiarygodności utrwalonego w niej przekazu zob. R. Rutkowski, ,A ja nazywam się Ari”. O najstarszej kronice islandzkiej i jej autorze [w:] Autor i jego dzieło w wiekach średnich, red. A. Laskowska, M. Sas, Warszawa 2014, s. 63-76 oraz przywoływana tam literatura przedmiotu. Ogólnie na temat staroislandzkich źródeł narracyjnych zob. J. Kristjáns son, Eddas and Sagas: Iceland's Medieval Literature, Reykjavík 2007; Sagi islandzkie. Zarys dziejów literatury staronordyckiej, red. J. Morawiec, Ł. Neubauer, Warszawa 2015.

3 Íslendingabók and Kristnisaga - The Book of Icelanders, and The Story of the Conversion, Viking Society for Northern Research Text Series, vol. XVIII, transl. by S. Grønlie, London 2006, s. 11-12.

4 Islandske Annaler indtil 1578, útg. G. Storm, Christiania 1888, s. 19, 59, 472. 
spisywał swą kronikę, Islandia była zatem jedynym krajem nordyckim, w którym regularnie pobierano dziesięcinę 5 .

Autor Íslendingabók starał się przekonać adresatów swego dzieła, że na Islandii obowiązkową daninę na Kościół udało się wprowadzić bez wyraźnego sprzeciwu dzięki wysokiej pozycji Gizurra Ísleifrsona. Biskup Skálholt miał się cieszyć większą popularnością wśród rodaków niż jakikolwiek inny jego krajan w historii (var ástscelli af öllum landsmönnum en hverr maðr annarra, peira er vér vitim hér á landi hafa verit), zgoda na ponoszenie kosztów dziesięciny miała być zaś wyrazem niezwykłego posłuszeństwa okazywanego mu przez wiernych (bat eru miklar jartegnir, hvat hlýðnir landsmenn váru peim manni) ${ }^{6}$. Późniejsi, XIII i XIV-wieczni sögumenn (redaktorzy sag) uważają z kolei, że w czasach przedchrześcijańskich islandzcy wodzowie pobierali od stowarzyszonych z nimi gospodarzy (bcendr, 1. poj. bóndi) obowiązkowe opłaty (hoftollr), z których finansowali utrzymanie pogańskich świątyń (zob. np. Eyrbyggja saga, 4. kafli). Sugerują tym samym, że dziesięcina mogła mieć na Islandii wcześniejsze analogie, a przez to budzić mniejszy opór niż w innych kra$j$ jach$^{7}$. Współcześni historycy upatrują przyczyn jej sprawnego wprowadzenia raczej w cechach samej dziesięciny - jej konstrukcja miała szczególnie faworyzować elity społeczne, w tym zwłaszcza goðar będących jedynymi osobami uprawnionymi do głosowania nad jej przyjęciem ${ }^{8}$.

Nie dysponujemy informacjami na temat kształtu, w jakim dziesięcina została wprowadzona na Islandii w 1097 roku. Wszystkie zachowane przekazy na ten temat są znacznie późniejsze, zaś najpełniejszy obraz znajdujemy dopiero w pochodzących z XIII wieku kopiach staroislandzkiego zbioru prawa zwanego Grágás9. Zgodnie z informacjami przekazanymi przez kompilatorów tego prywatnego spisu norm prawnych każdy dorosły Islandczyk, bez względu na płeć, był zobligowany do stawienia się raz w roku na spotkanie wspólnoty sąsiedzkiej (hreppr), do której należał, publicznego wyliczenia wszystkich składników swojego majątku ruchomego i nieruchomego, jakim dysponował w okresie tak zwanych dni przeprowadzki (fardagar), oraz określenia jego wartości. Powinien to zrobić, przysięgając na Biblię

5 J. Jóhannes s on, op. cit., s. 148-149. Przed próbą wprowadzenia przez Kanuta IV obowiązkowych opłat na rzecz Kościoła w żadnym z krajów skandynawskich tamtejsi władcy nie pobierali regularnych podatków. Wcześniejsze świadczenia publiczne polegały tylko na ponoszeniu kosztów wyposażania armii i/lub osobistego udziału w wyprawach zbrojnych (leiðangr). Opór, z jakim na tych terenach spotkała się dziesięcina, nie powinien więc zaskakiwać. Zob. S. Bagge, Cross and Scepter: The Rise of the Scandinavian Kingdoms from the Vikings to the Reformation, Princeton 2014, s. 108-109.

6 Íslendingabók..., 10. kafli; por. Kristni saga, 15 kafli.

7 J. Jóhannesson, op. cit., s. 56.

8 Zob. np. ibidem, s. 149; J.L. Byock, Viking Age Iceland, London 2001, s. 326-328; W.I. Miller, Bloodtaking and Peacemaking: Feud, Law, and Society in Saga Iceland, Chicago 1990, s. 36.

9 Wszystkie odwołania do Grágás dotyczą kanonicznego wydania opublikowanego w: Laws of Early Iceland: Grágás, the Codex Regius of Grágás with Material from Other Manuscripts, vol. III, red. A. Dennis, P. Foote, R. Perkins, Winnipeg 1980. Aby ułatwić odnajdywanie odpowiednich fragmentów w tekście, używam zapisu, w którym liczba rzymska oznacza tom, liczba arabska - paragraf, zaś liczba arabska zapisana subskryptem - stronę. Na przykład GII $255_{222}$ wskazuje na paragraf 255 opublikowany w drugim tomie Grágás na stronie 222. 
$\left(\text { GII } 255_{222}\right)^{10}$. Nadzór nad tymi czynnościami sprawowali funkcjonariusze wspólnoty zwani sóknarmenn. Niewywiązanie się ze wspomnianych obowiązków zagrożone było karą grzywny. Za niestawienie się na spotkanie bądź niewysłanie zastępcy w przypadku niemożności osobistego uczestnictwa pobierano 3 marki, a za odmowę złożenia przysięgi lub zaniżenie wartości majątku o co najmniej jedną czwartą 12 marek (GII $\left.255_{223-224}\right)^{11}$. Dopełnienie wyżej wymienionych czynności było niezbędne do określenia podmiotów zobowiązanych do uiszczenia dziesięciny i ustalenia jej wysokości.

Obowiązek zapłaty tiund spoczywał przede wszystkim na osobach zdolnych do ponoszenia kosztów opłat wiecowych (pingfararkaup), a więc gospodarzach - zarówno właścicielach, jak i dzierżawcach - którzy mieli przynajmniej tyle wolnych od wszelkich obciążeń mlecznych krów bądź łodzi rybackich (lub innych dóbr stanowiących ich równowartość), ilu członków liczyło dane gospodarstwo, oraz dysponowali „wszystkim innym, bez czego nie może funkcjonować domostwo” (GI 89 $\left.{ }_{150}\right)$. Pozostali Islandczycy podlegali obowiązkowi płacenia dziesięciny jedynie wtedy, gdy wartość ich majątku była co najmniej równa prawnie określonemu minimum.

Najniższą wartość majątku, od którego należało odprowadzić dziesięcinę, staroislandzkie prawo ustanawiało na poziomie 10 legalnych uncji (lögaurar, 1. poj. lögeyrir $)^{12}$. Majątek ten musiał być przy tym wolny od wszelkich obciążeń i nie wliczano doń codziennego ubioru oraz kilku innych enumeratywnie wyliczonych składników (patrz niżej). Każdy, kto dysponował mieniem równym tej kwocie lub wyższym, był zobowiązany do zapłaty dziesięciny, o ile nie miał na utrzymaniu tak zwanych osób zależnych (ómagar), czyli małoletnich ${ }^{13}$ bez własnych środków, niedołężnych rodziców bądź innych osób niezdolnych do utrzymania się z pracy własnych rąk (GII 255 221-222).

Wysokość dziesięciny uiszczanej przez osoby spełniające wymienione warunki zależała od wartości majątku. Dla tych, których mienie nie przekraczało wartości 10 lögaurar, wynosiła ona równowartość 1 łokcia samodziału, przy maksymalnie 20 lögaurar były to 2 łokcie samodziału, przy nie więcej niż 40 lögaurar - 3 łokcie, do 60 lögaurar - 4 łokcie, do 80 lögaurar - 5 łokci, a przy 100 lub więcej lögaurar - 6 łokci samodziału (GII $255_{221}$ ). Islandzkie tíund można więc uznać za swoisty podatek od własności o charakterze regresywnym - im większy majątek osoby

10 Dni przeprowadzki to ostatnie cztery dni maja. Wówczas Islandczycy ustalali swój domicyl na kolejny rok $\left(G I 78_{125-128}\right)$.

${ }_{11}$ Warto w tym miejscu nadmienić, że grzywna 12 marek jest wyjątkowo wysoka. Standardowa wysokość grzywny w Grágás to 3 marki (okazjonalnie można spotkać też grzywnę sześciomarkową). Tak wysoka kara, stanowiąca wielokrotność najwyższej dziesięciny (patrz niżej), może sugerować problemy ze ściągalnością tíund.

12 Jedna legalna uncja była równa sześciu łokciom samodziału (vaðmál), tj. wełnianej tkaniny stanowiącej najpowszechniej wykorzystywany na Islandii środek płatniczy i główny islandzki towar eksportowy. Na temat systemu pieniądza towarowego funkcjonującego w średniowieczu na Islandii zob. S.H. Gullbekk, Money and Its Use in the Saga Society: Silver, Coins and Commodity Money [w:] Viking Settlements and Viking Society Papers from the Proceedings of the Sixteenth Viking Congress, ed. S. Sigmundsson, Reykjavík 2011, s. 176-188.

13 Chłopców do 16. roku życia i niezamężnych kobiet, które nie rozpoczęły 20. roku życia. 
zobowiązanej do uiszczenia dziesięciny, tym niższy jej procentowy wymiar. Najniższa dziesięcina o równowartości jednego łokcia samodziału stanowiła 1/60 wartości majątku płatnika, najwyższa o równowartości 6 łokci samodziału stanowiła 1/100 wartości jego mienia ${ }^{14}$.

Zgodnie z normami zawartymi w Grágás dziesięciny o wysokości nieprzekraczającej wartości 5 łokci samodziału miały być przeznaczone na pomoc osobom potrzebującym (burfamenn, GII 256 224 ), chyba że biskup podjął jednorazową decyzję, iż w danym roku powinny one zostać przekazane na utrzymanie wskazanych przez niego kościołów (GII 259 230). Najwyższą dziesięcinę, o wartości 6 łokci samodziału, określano jako podzielną (skiptitiund). Podlegała ona podziałowi na cztery równe częścici ${ }^{15}$.

Pierwsza część (burfamannatíund) - tak jak dziesięcina niepodzielna - miała trafiać do osób potrzebujących. Otrzymywali ją gospodarze dysponujący zbyt małym majątkiem, by płacić dziesięcinę, i ci, na których spoczywał prawny obowiązek opieki nad większą liczbą osób zależnych, niż byli oni w stanie utrzymać. Drugą część, zwaną dziesięciną biskupią (biskupstíund), dostawał zwierzchnik diecezji. Z trzeciej części miano finansować lokalne kościoły (kirkjutiund), z czwartej zaś pokrywać koszty utrzymania pełniących w nich posługę księży (preststíund).

Poborem i rozdysponowywaniem purfamannatíund zajmowały się wspólnoty sąsiedzkie. Biskupstíund była zbierana przez osobę wskazaną przez biskupa podczas okresowego objazdu diecezji ${ }^{16}$. Egzekucja płatności kirkjutiund i preststíund należała z kolei do osoby sprawującej zarząd nad właściwym kościołem parafialnym ${ }^{17}$.

Majątek wart minimum 100 lögaurar, od którego pobierano najwyższą - podzielną - dziesięcinę, stanowił równowartość co najmniej 5 mlecznych krów lub 4 rocznych wynagrodzeń za pracę na farmie ${ }^{18}$. $\mathrm{Z}$ tego też względu skiptitíund w praktyce uiszczali jedynie ludzie względnie dobrze sytuowani, przede wszystkim gospodarze zdolni do ponoszenia opłat wiecowych. Pozostali Islandczycy bądź nie płacili dziesięciny wcale, bądź też była ona tak niska, że nie dokonywano jej podziału i w całości przeznaczano na pomoc osobom potrzebującym.

14 Proporcje pośrednie to odpowiednio 1/60 dla 20 lögaurar, 1/80 dla 40 lögaurar, 1/90 dla 60 lögaurar i 1/96 dla 80 lögaurar.

15 Podział dziesięciny na cztery części obowiązywał już wcześniej w niemieckim Kościele. Zob. J. Jóhannesson, op. cit., s. 175.

16 Zgodnie z normami zawartymi w Grágás biskup Hólar miał odwiedzić każdą wspólnotę sąsiedzką funkcjonującą na terenie jego diecezji co najmniej raz w roku, a biskup Skálholt nie rzadziej niż raz na trzy lata, celem „konsekracji kościołów, kaplic i oratoriów, udzielania sakramentu bierzmowania i wysłuchiwania spowiedzi” $\left(G I 5_{35-36}\right)$. W trakcie spotkań z wiernymi w jednym z kościołów leżących na terenie wspólnoty biskupi mieli też ogłosić, komu należy dostarczyć biskupstíund.

17 Z fragmentów GII $258_{226}$ oraz GII $260_{230}$ wynika, że biskup dla danej diecezji miał wskazywać kościoły uprawnione do otrzymywania dziesięciny, współcześni badacze przyjmują jednak, że normy te stosowano jedynie w sytuacji wystąpienia sporu między kilkoma osobami sprawującymi pieczę nad różnymi świątyniami. Zob. O. Vesteins s on, op. cit., s. 73-74.

18 Na przełomie XII i XIII w. wartość krowy mlecznej była równa wartości 72-100 łokci samodziału. Zob. Njal's saga, transl., introduction and notes by R. Cook, London 2001, s. 311. 
Oceniając kształt islandzkiego tíund z perspektywy korzyści, jakie przynosił podmiotom uprawnionym do jego pobierania, łatwo zrozumieć, dlaczego za wprowadzeniem tej opłaty mogli się opowiadać przedstawiciele lokalnych elit. Połowa skiptitíund miała być pobierana od wiernych przez zarządców kościołów, te zaś na Islandii podlegały prywatnej kontroli sprawowanej przez ich kolatorów. Ponadto do majątku, od którego pobierano dziesięcinę, nie wliczano wodzostw, w tym przypadku traktowanych jako „władztwo, nie zaś majątek” (velldi er pat en ceigi fé), ani „własności przeznaczonej ku chwale Boga”, czyli darowizn na rzecz Kościoła (ziemi, żywego inwentarza, budynków) oraz szat, ksiąg i przedmiotów liturgicznych należących do księży (pozostałe składniki majątku tych ostatnich podlegały dziesięcinie na ogólnych zasadach) ${ }^{19}$.

Osoby zamożne, dokonując odpowiednich rozporządzeń, mogły więc wyłączyć znaczną część swojego majątku spod dziesięciny, a jeśli były one kolatorami kościołów - ubiegać się także o kirkjutíund i preststíund. Uchwalenie dziesięciny przysporzyło im zatem nowego źródła stałych przychodów. Zdaniem większości współczesnych badaczy na Islandii, w przeciwieństwie do innych krajów kręgu kultury skandynawskiej, wspomnianą daninę udało się wprowadzić bez wyraźnego oporu, ponieważ przynosiła ona istotne korzyści elitom społecznym, w tym zwłaszcza goðar dysponującym prawem głosu w Zgromadzeniu Prawodawczym, w którym wedle tradycji w 1097 roku podjęto uchwałę o poborze obowiązkowej dziesięciny. Dla przykładu, jak stwierdza William I. Miller,

wodzostwa [...] nie podlegały dziesięcinie, podobnie jak i majątek podarowany kościołowi, i to nawet wówczas, gdy kościół ten znajdował się pod wyłączną kontrolą darczyńcy. Ostatnie z tych zwolnień sprawiało, iż właściciele prywatnych kościołów byli w stanie wyłączyć spod dziesięciny cały swój majątek. Na gruncie tej reguły i przy uwzględnieniu faktu, iż połowa kwoty pobieranej od osób trzecich była przeznaczona na utrzymanie kościoła i związanego z nim księdza, możemy zacząć dostrzegać, dlaczego w źródłach nie zachowały się relacje na temat sprzeciwu bogatych i możnych wobec dziesięciny - mieli oni świadomość istnienia tych luk prawnych i ochoczo z nich korzystali ${ }^{20}$.

Powyższa hipoteza, jakkolwiek dość powszechnie akceptowana w literaturze przedmiotu, jest jednak problematyczna. Przede wszystkim - wbrew temu, co wydają się sądzić jej zwolennicy - nie daje ona wcale odpowiedzi na pytanie, dlaczego na Islandii dziesięcina została wprowadzona bez wyraźnego oporu społecznego, a jedynie dlaczego opowiadali się za nią goðar. Pytania te nie są jednak tożsame. W omawianym okresie Islandczycy nie posiadali zorganizowanego aparatu wykonawczego, przez co egzekucja obowiązujących na wyspie norm prawnych pozostawała w gestii samych zainteresowanych (w zależności od stanu faktycznego - potencjalnych beneficjentów, ale też pokrzywdzonych/poszkodowanych bądź też osób im bliskich

19 Od dziesięciny wolne były również zapasy domowe, które pozostały z poprzedniej wiosny, mosty oraz przeprawy rzeczne, a także - w przypadku osób najbiedniejszych - ubrania codziennego użytku $\left(\right.$ GII $\left.255_{221}\right)$.

20 W.I. Miller, op. cit., s. 36. 
lub tych, którzy nabyli od nich odpowiednie roszczenia) ${ }^{21}$. Wodzowie, a także inni kolatorzy prywatnych kościołów, z pewnością popierali pobór dziesięciny, ale można mieć wątpliwości co do tego, czy wszyscy bcendr, na których spoczywał obowiązek jej uiszczania, chcieli ją płacić, zwłaszcza że mogła ona być traktowana jako potwierdzenie ich podległości. Problem ten okazuje się szczególnie istotny, jeśli przyjmiemy (jak to czyni wielu współczesnych historyków), że na przełomie XI i XII wieku gospodarze zdolni do ponoszenia opłat wiecowych wciąż jeszcze stanowili na Islandii względnie jednorodną grupę o stosunkowo niewielkim zróżnicowaniu majątkowym, a ich pozycja społeczna nie odbiegała nadto od pozycji goðar (których status był znacznie bliższy primus inter pares niż kontynentalnym panom feudalnym $)^{22}$. Ponadto omawiana hipoteza nie uwzględnia tego, że do beneficjentów dziesięciny nie zaliczali się wyłącznie przedstawiciele elit - jedną czwartą skiptitíund przeznaczano wszak na pomoc osobom potrzebującym. Co więcej, Islandczycy niebędący gospodarzami - a więc zdecydowana większość mieszkańców wyspy - nie dysponowali dostatecznie dużym majątkiem, by płacić podzielną dziesięcinę, a zatem transferować środki na rzecz wodzów i innych kolatorów prywatnych kościołów. Potencjalne przychody czerpane przez tych ostatnich z dziesięciny nie musiały więc być duże, a jednocześnie próba jej poboru mogła doprowadzić do konfliktu z innymi wolnymi gospodarzami, bez których aktywnego wsparcia wodzowie nie byli w stanie odgrywać istotnej roli politycznej.

W dalszej części niniejszej pracy podejmę się próby rozwiązania zasygnalizowanych wyżej problemów, odwołując się do jednego z podstawowych narzędzi ekonomii publicznego wyboru - teorii grup interesu ${ }^{23}$.

III. Analizowanie decyzji politycznych pod kątem korzyści, jakie przynoszą one grupom interesu, ma długą tradycję w naukach społecznych. Początkowo dominującym podejściem w tym względzie było spojrzenie politologiczne, określane współcześnie mianem teorii pluralistycznejej ${ }^{24}$. Jej zwolennicy wychodzili z założenia, że naturalną konsekwencją życia społecznego jest formowanie się w obrębie wszystkich zbiorowości ludzkich grup interesu, które zabiegają o realizację własnych celów, konkurując przy tym z innymi zbiorowymi podmiotami ${ }^{25}$. Jakkolwiek podejście to przyjmuje różne postaci, ich wspólną cechą jest skupianie analiz na działaniach

21 D.D. Friedman, Private Creation and Enforcement of Law: A Historical Case, ,Journal of Legal Studies" 1979, vol. 8, no. 2, s. 399-415.

22 J.L. Byock, op. cit., s. 118-141; J.V. Sigurðsson, Chieftains and Power in the Icelandic Commonwealth, Odense 1999, passim.

23 Ogólnie na temat teorii grup interesu zob. D.A. Farber, P.P. Frickey, Law and Public Choice: A Critical Introduction, Chicago 1991, s. 12-37. O możliwości jej stosowania w odniesieniu do społeczności przedpaństwowych zob. R. Blanton, L. Fargher, Collective Action in the Formation of PreModern States, New York 2008, s. 5-24. Przykładem jej użycia w ostatnim z zakresów może być praca: M. Levi, Of Rule and Revenue, Berkeley 1989.

24 Zob. H.B. Mawhinney, Theoretical Approaches to Understanding Interest Groups, „Educational Policy" 2001, vol. 15, no. 1, s. 187-214.

25 Zob. np. A.F. Bentley, The Process of Government, Chicago 1908; E. Latham, The Group Basis of Politics, Ithaca 1952; D. Truman, The Governmental Process, New York 1958. 
zbiorowych aktorów, jakimi są grupy interesu, z niemalże całkowitym pominięciem motywacji, wartości lub celów tworzących je jednostek. Teoria pluralistyczna, choć wciąż popularna i nadal często stosowana przez przedstawicieli różnych dyscyplin, została odrzucona w połowie lat 60 . XX wieku przez ekonomistów zarzucających jej nieuprawnione zrównanie występowania między jednostkami wspólnoty interesu ze zdolnością do podejmowania przez nie zorganizowanych działań zmierzających do ich osiągnięcia ${ }^{26}$.

Ekonomiści zajmujący się analizą funkcjonowania „rynku politycznego” rozróżniają dwa rodzaje podmiotów zbiorowych - wspólnoty interesu oraz grupy interesu. Te pierwsze stanowią zbiór jednostek mających wspólne cele, drugie są zbiorowościami zdolnymi do podejmowania zorganizowanych działań i reprezentowania wspólnych interesów wobec władzy publicznej. Rozróżnienie to jest istotne, ponieważ aby grono jednostek było w stanie osiągać wspólne cele, tworzona przez nie autogeniczna wspólnota jednostek musi zostać przekształcona w grupę, a ta - wbrew bardzo często przyjmowanemu implicite założeniu - rzadko (jeśli w ogóle) formuje się w sposób spontaniczny ${ }^{27}$.

Głównym problemem założenia o samorzutnym kształtowaniu się grup interesu okazuje się nieuwzględnianie w nim motywów przyświecających jednostkom tworzącym wspólnotę, w tym zwłaszcza kalkulacji związanych z bilansem korzyści i kosztów zbiorowego działania. Jeśli odpowiednia decyzja władz przyniesie pożytki wszystkim członkom wspólnoty interesu (tj. gdy nie ma możliwości wykluczenia któregokolwiek z grona potencjalnych beneficjentów ewentualnego transferu), a uczestnictwo w grupie i pokrywanie kosztów jej funkcjonowania mają charakter dobrowolny, to $\mathrm{w}$ interesie każdego członka z osobna leży powstrzymywanie się od partycypacji w ponoszeniu nakładów grupowych wysiłków i próba tak zwanej jazdy na gapę (ang. free riding) ${ }^{28}$. Im silniejszy jednak bodziec skłaniający do unikania kosztów, tym trudniej przekształcić wspólnotę interesu w grupę aktywnie zabiegającą o jego realizację ${ }^{29}$. W takim przypadku korzyści, o które zabiegają grupy interesu, stanowią swoiste dobra publiczne (niewykluczalne z konsumpcji, ang. non-excludable), te zaś zwykle świadczone są na poziomie uważanym za suboptymalny ${ }^{30}$.

Problem gapowicza nie dotyczy wszystkich grup w takim samym stopniu. Wyniki badań prowadzonych w ramach ekonomii publicznego wyboru wskazują, że jego przełamanie jest możliwe, na przykład przez wprowadzenie przymusu uczestnictwa

26 Zob. zwłaszcza: M. Olson, The Logic of Collective Action: Public Goods and the Theory of Groups, Cambridge 1965, passim.

27 Ekonomiczną teorię grup interesu przystępnie omówiono w pracy: P. Tłaczała, Analiza grup interesu [w:] Teoria wyboru publicznego. Wstęp do ekonomicznej analizy polityki i funkcjonowania sfery publicznej, red. J. Wilkin, Warszawa 2005, s. 184-203.

28 G.S. Becker, A Theory of Competition Among Pressure Groups for Political Influence, „Quarterly Journal of Economics" 1983, vol. 98, no. 3, s. 380.

29 G.J. Stigler, Free Riders and Collective Action: An Appendix to Theories of Economic Regulation, „Bell Journal of Economics and Management Science” 1974, vol. 5, no. 2, s. 359-365.

30 G. Tullock, The Economics of Special Privilege and Rent Seeking, New York 1989, s. 43-45. Szerzej na temat dóbr publicznych zob. teksty zebrane w publikacji: The Theory of Market Failure: A Critical Examination, ed. T. Cowen, Fairfax 1988. 
potencjalnych beneficjentów w działaniach grupy i związanych z nimi nakładach. Skuteczne okazuje się również sprywatyzowanie korzyści przez ograniczenie grona podmiotów, które faktycznie je odniosą, wyłącznie do członków wspólnoty ponoszących koszty zorganizowanego zabiegania o nie. Zdolności grup w tym względzie są z kolei uzależnione przede wszystkim od ich wielkości, stopnia heterogeniczności, czyli zróżnicowania poziomu zainteresowania poszczególnych członków realizacją wspólnych postulatów, sposobu dystrybucji korzyści między beneficjentów i otoczenia instytucjonalnego, w którym one działają, a zwłaszcza od tego, czy już w jakimś stopniu są one zorganizowane. Odkryte podczas tych badań prawidłowości można streścić następująco: 1) małe wspólnoty interesu łatwiej przekształcić w grupy interesu niż duże, gdyż mają niższe koszty transakcyjne i są one trudniejsze do uniknięcia; 2) heterogeniczność grupy sprzyja osiąganiu jej postulatów - wraz ze wzrostem zróżnicowania maleje potrzeba podejmowania zbiorowych działań, gdyż ciężar zapewnienia realizacji interesu biorą na siebie podmioty spodziewające się osiągnąć największe korzyści; 3) formowaniu się grup interesu sprzyja istnienie sformalizowanej struktury instytucjonalnej opierającej się na wielu powiązanych ze sobą organizacjach, przy czym przynależność do części tych organizacji jest obowiązkowa (tzw. system korporatywistyczny). Największy potencjał do realizacji swych interesów mają zatem stosunkowo małe wspólnoty o wysokim stopniu heterogeniczności, działające w otoczeniu instytucjonalnym umożliwiającym im łatwe formowanie grup ${ }^{31}$.

Z zarysowanej wyżej ekonomicznej teorii grup interesu wynika, że aby ustalić, dlaczego biskupowi Gizurrowi udało się doprowadzić do przyjęcia dziesięciny bez dostatecznie silnego oporu ze strony Islandczyków, by pozostawił on ślad w źródłach, należy zidentyfikować wspólnotę interesów, która mogła być zainteresowana wprowadzeniem tíund, określić jej liczebność i stopień heterogeniczności oraz ustalić zdolność do sformowania w jej obrębie koalicji.

Współcześni badacze za głównych zwolenników wprowadzenia tej daniny uznają goðar. Tylko oni - obok islandzkich biskupów - mogli głosować w Zgromadzeniu Prawodawczym, całkowicie kontrolowali więc legislację, przez co bez ich aktywnego wsparcia niemożliwe było uchwalenie jakiegokolwiek nowego prawa. Wedle sögumenn to właśnie $\mathrm{z}$ ich grona mieli się wywodzić kolatorzy większości prywatnych kościołów wybudowanych na Islandii w XI wieku ${ }^{32}$, oni też z uwagi na relacje, w jakich pozostawali z innymi gospodarzami, potrafili wyegzekwować płatność kirkjutiund i preststiund. Także konstrukcja prawna samej dziesięciny - zarówno w zakresie podmiotów uprawnionych do jej poboru, jak i w odniesieniu do wyłączeń majątkowych - wydaje się szczególnie sprzyjająca dla goðar. Teza, zgodnie z którą islandzcy wodzowie dostrzegli na przełomie XI i XII wieku silny związek między swą prywatną fortuną a interesami rodzącego się lokalnego Kościoła, bardzo wyraźnie ujawnia się również w licznym przyjmowaniu przez nich w tym okresie święceń kapłańskich. Jak bowiem wynika z relacji zachowanej w Kristni saga, za czasów posługi biskupiej Gizurra Ísleifrsona większość możnych mężów została księżmi,

31 P. Tłaczała, op. cit., s. 188-190.

32 O. Vesteinsson, op. cit., s. 37-45. 
mimo że byli oni wodzami (bá váru flestir virðingamenn lcerðir ok vígðir til presta, pó at höfdingjar vari $)^{33}$.

Poparcie ze strony goðar okazało się wystarczające do przyjęcia prawa o obowiązkowej dziesięcinie, ale nie do jego stosowania. Przy braku zorganizowanej władzy wykonawczej za faktycznie obowiązujące na Islandii (tj. podlegające egzekucji) normy należy uznać jedynie te, które cieszyły się względnie szeroką akceptacją społeczną i/lub do których wyegzekwowania dało się zmobilizować dostatecznie dużą siłę, by powstrzymać/ukarać osoby je naruszające ${ }^{34}$. Do realizacji tego ostatniego wymogu goðar potrzebowali wsparcia ze strony co najmniej części stowarzyszonych z nimi gospodarzy. W kontekście prowadzonych rozważań oznacza to, że wspólnota interesu popierająca pobór tíund musiała być szersza, niż się zwykle zakłada w literaturze przedmiotu. Analizując zachowane źródła dotyczące kształtu islandzkiej dziesięciny, można wskazać kilka innych środowisk, które spodziewały się odniesienia korzyści w związku z jej ustanowieniem.

Religijne uzasadnienie dla dziesięciny nakazuje w pierwszej kolejności zastanowić się nad korzyściami, jakie w związku z jej poborem mógłby odnieść Kościół rozumiany zarówno jako instytucja, jak i wspólnota wiernych. Do czasu wprowadzenia tíund działalność islandzkiego Kościoła była w dużej mierze prywatnym przedsięwzięciem rodu Haukdælir, z którego wywodziło się dwóch pierwszych lokalnych biskupów i którego majątek stanowił główne źródło jego finansowania (Skálholt - siedziba pierwszego islandzkiego biskupstwa - był pierwotnie prywatnym gospodarstwem Gizzura Ísleifrsona odziedziczonym po ojcu, biskupie Ísleifurze Gizzurarsonie) ${ }^{35}$. Pozyskanie stałego, dodatkowego względem środków własnych źródła przychodu w sposób oczywisty leżało więc w interesie „ojców założycieli” islandzkiego Kościoła. Beneficjentem nowej daniny mogła się jednak stać także wspólnota wiernych.

Okres co najmniej trzech pokoleń od konwersji, tradycyjnie datowanej na rok 999 lub 1000, wydaje się dostatecznie długi, by na Islandii dokonała się faktyczna chrystianizacja znacznej części ludności (w tym zwłaszcza elity społecznej) obejmująca wykształcenie się wśród niej potrzeby uczestniczenia w ceremoniale religijnym. Tymczasem z zachowanych źródeł wynika, że XI-wieczny islandzki Kościół najprawdopodobniej nie potrafił efektywnie wywiązywać się z obowiązków duszpasterskich ${ }^{36}$. Przekazy, zgodnie z którymi jeszcze w latach 60 . XI stulecia na wyspie prowadzili swą działalność zagraniczni biskupi misyjni (Íslendingabók, 8. kafli), sugerują, że liczba lokalnych księży na przeszło pół wieku po oficjalnym chrzcie Islandii wciąż była niewielka ${ }^{37}$. W czasach posługi biskupa Ísleifa przedstawiciele elit mieli zacząć wysyłać swoich synów po nauki do Skálholt, ale niebudzący wątpliwości wzrost

33 Kristni saga, 17. kafli.

34 J.L. Byock, op. cit., s. 118-137.

35 J. Jóhannesson, op. cit., s. 144-153.

36 O. Vesteinsson, op. cit., s. 179-182.

37 H.S. Kjartansson, Thin on the Ground: Legal Evidence of the Availability of Priests in the $12^{\text {th }}$ Century Iceland [w:] Church Centers in Iceland from the $11^{\text {th }}$ to the $13^{\text {th }}$ Century and Their Parallels in Other Countries, ed. H. porláksson, Reykholt 2005, s. 95-102. 
liczby księży nastąpił dopiero z początkiem wieku XII za sprawą przyznania przez biskupa Gizurra święceń kapłańskim wielu prominentnym goðar (Kristni saga, 17. kafli). Można więc podejrzewać, że do końca XI wieku księży na Islandii było mniej niż prywatnych kościołów, przez co w wielu (większości?) z nich nabożeństwa odbywały się najprawdopodobniej sporadycznie i nieregularnie ${ }^{38}$. Wprowadzenie obowiązkowej dziesięciny, której jedna część miała zostać przeznaczona przez osoby sprawujące kontrolę nad właściwym kościołem na utrzymanie odprawiającego w nim posługę księdza, mogło więc istotnie poprawić sytuację w tym względzie. Uspołecznienie kosztów zaspokajania potrzeb religijnych mogło więc być postrzegane jako korzyść przez ogół wiernych, zwłaszcza że odbyło się stosunkowo niewielkim nakładem jednostkowym i przy zaangażowaniu wyłącznie osób względnie dobrze sytuowanych (z uwagi na odpowiedni cenzus majątkowy preststíund płacili niemal wyłącznie gospodarze zdolni do ponoszenia opłat wiecowych).

Korzyści we wprowadzeniu dziesięciny mogli też dopatrywać się prominentni kolatorzy kościołów nienależący do grona goðar. Z przekazów zawartych w źródłach narracyjnych wynika, że większość kolatorów 35 kościołów, jakie miały zostać wzniesione na Islandii w XI wieku, stanowili wodzowie ${ }^{39}$. Informacje te są trudne do weryfikacji, współcześni badacze skłaniają się jednak ku tezie, iż goðar nie byli jedynymi osobami, które budowały przy swoich gospodarstwach prywatne kościoły. Niewykluczone, że jeszcze w czasie organizacji pierwszego islandzkiego biskupstwa (tj. między ok. 1060 a 1080 r.) wznoszenie przydomowych kaplic stało się symbolem relatywnie wysokiej pozycji społecznej ich fundatorów ${ }^{40}$. Zdolność do sfinansowania budowy prywatnego kościoła nie musi jednak oznaczać zdolności do utrzymywania go jako miejsca odprawiania regularnych nabożeństw, zwłaszcza przy uwzględnieniu wysokich kosztów wyposażenia eucharystycznego oraz utensyliów liturgicznych, które w islandzkich warunkach musiały być sprowadzane z zagranicy. Ustanowienie obowiązkowej dziesięciny mogło jednak istotnie ograniczyć ciężar tych wydatków. Kolatorzy prywatnych kościołów, których nie było stać na ponoszenie kosztów regularnych mszy, mogli więc upatrywać w tíund szansy na poprawę swojej sytuacji. Pobór kirkjutiund i preststíund nie tylko umożliwiłby im przekształcenie stricte prywatnej świątyni w lokalne centrum kultu, ale także istotnie wzmacniałby ich pozycję względem sąsiadów.

Powyższe rozważania pozwalają nam na zidentyfikowanie szerokiego i zarazem heterogenicznego grona podmiotów, które mogły być zainteresowane wprowadzeniem trzech z czterech części podzielnej dziesięciny - biskupstiund, kirkjutiund i preststíund. Większość Islandczyków zobowiązanych do uiszczania dziesięciny z uwagi na zbyt mały majątek własny nie płaciła jednak skiptitíund. Pozyskiwane od nich środki w całości przeznaczano na pomoc osobom potrzebującym. $\mathrm{Na}$ ten cel przekazywano również ostatnią, czwartą część podzielnej dziesięciny purfamannatiund, pobieraną od relatywnie zamożnych gospodarzy. Istotny odsetek

38 B. Eypórsson, History of the Icelandic Church 1000-1300: Status of Research [w:] Church Centers..., s. 26-27.

39 O. Vesteinsson, op. cit., s. 37.

40 B. Eypórsson, op. cit., s. 21. 
środków gromadzonych co roku w ramach tíund trafiał więc do osób, które nie należały do społecznej elity. Sytuacja ta wymaga dodatkowego wythumaczenia, ponieważ jest mało prawdopodobne, by beneficjenci tych transferów - z uwagi na swój niski status społeczny - mogli odgrywać istotną rolę we wspólnocie interesu opowiadającej się za wprowadzeniem obowiązkowej dziesięciny.

Wskazówki w tym względzie może nam wszelako dostarczyć znaczący udział wspólnot sąsiedzkich w ściąganiu i rozdysponowywaniu dziesięciny. Hreppar (1. poj. hreppr) stanowiły związek co najmniej 20 gospodarstw, których zarządcy (właściciele bądź dzierżawcy) byli zdolni do ponoszenia opłat wiecowych. Przynależność do którejś z wspólnot była obowiązkowa, a one same miały charakter terytorialny ${ }^{41}$. Hreppar nadzorowały korzystanie ze wspólnych pastwisk, zarząazały systemem ubezpieczeń wzajemnych przed skutkami nieszczęśliwych zdarzeń (np. pożarów), a nade wszystko odpowiadały za organizowanie pomocy członkom wspólnoty znajdującym się w trudnej sytuacji ${ }^{42}$.

Udzielanie wsparcia osobom pozbawionym środków do życia, a zarazem z powodu wieku, stanu zdrowia lub ułomności niezdolnym do utrzymania się z pracy własnych rąk (ómagar, l. poj. ómagi) ${ }^{43}$ stanowiło obowiązek ich najbliższych krewnych ${ }^{44}$. W przypadku ich braku ciężar utrzymania wymienionych osób przejmowali na siebie członkowie wspólnoty. Zadaniem sóknarmenn (funkcjonariuszy wspólnoty wybieranych spośród grona gospodarzy na roczne kadencje) było w takich sytuacjach przekazanie ómagar pod okresową opiekę lokalnym gospodarzom, dysponującym odpowiednim, wolnym od obciążeń majątkiem (GII 234 $\left.{ }_{185-186}\right)$. Bcendr, którzy odmówili przyjęcia do swych domostw przydzielonych im osób zależnych, bądź też uchylali się od ich utrzymania na prawnie określonym poziomie, narażali się na grzywnę w wysokości 3 marek (GII 234 $\left.{ }_{186-189}\right)$.

Rozdzielenia ómagar między gospodarzy dokonywano z uwzględnieniem zdolności finansowych tych ostatnich i na stosunkowo krótkie okresy, tak by zapewnianie osobom zależnym wiktu i opierunku nie stanowiło zagrożenia dla bieżącego

${ }^{41}$ Jeśli gospodarstwo leżało na granicy dwóch lub więcej hreppar, obejmujących minimum 20 pingfararkaupsbcendr, jego właściciel miał prawo dokonania wyboru, do której z nich chce należeć ( GII $\left.234_{185}\right)$. Na temat wspólnot sąsiedzkich i ich funkcjonowania zob. G. Cattaneo, Reflection on the Hreppar: The Communities of the Inhabitants of Medieval Iceland, „Cahiers de Civilisation Médiévale” 2014, vol. 57, no. 2, s. 113-131; M. Stein-Wilkeshuis, The Right to Social Welfare in Early Medieval Iceland, „Journal of Medieval History” 1982, vol. 8, no. 4, s. 343-352.

42 Szerzej na ten temat w: J. Jóhannes son, op. cit., s. 83-89.

43 A tylko takie mogły liczyć na pomoc. Ci, którzy byli w pełni sprawni, a zajmowali się żebractwem lub włóczęgostwem, podlegali karze pełnej banicji $\left(G I 82_{135}\right)$. Nawet bez jej orzeczenia nie mogli oni liczyć na ochronę prawną. Z zachowanych źródeł narracyjnych wynika, że często stawali się ofiarami przemocy, w tym kastracji. Zob. G. Nordal, Ethics and Action in Thirteenth-Century Iceland, Odense 1998, s. 200-201.

${ }^{44} \mathrm{~W}$ odniesieniu do krewnych $\mathrm{w}$ linii prostej ten obowiązek miał szczególnie dalekosiężne konsekwencje. W przypadku gdy dorosłe dziecko nie dysponowało dostatecznymi środkami, by utrzymać niedołężnego rodzica (w pierwszej kolejności matki), było zobowiązane oddać się w niewolę dłużną (skuldaprceldómr) swemu najbliższemu krewnemu, który mógł pokryć koszty utrzymania osoby zależnej. Gdyby zaś to rodzic nie był w stanie łożyć na swe małoletnie dziecko, wówczas miał on do wyboru bądź to samemu oddać się w niewolę dłużną, bądź też oddać w nią swe dziecko ( $G I I 128_{29-30}$ ). 
funkcjonowania poszczególnych gospodarstw. Środki przeznaczane przez bcendr na utrzymanie ludzi oddanych im pod opiekę pochodziły jednak z ich własnych zasobów i mogły stanowić istotne obciążenie dla „domowego budżetu”, zwłaszcza w okresach kryzysu spowodowanego zdarzeniami niepodlegającymi kontroli, na przykład szczególnie długą zimą. System ten, chociaż odgrywał istotną rolę w przeciwdziałaniu włóczęgostwu i kradzieżom (czynom uznawanym przez średniowiecznych Islandczyków za bardzo niebezpieczne i szczególnie hańbiące ${ }^{45}$ ), mógł więc jawić się wielu gospodarzom jako dalece problematyczny. Wprowadzenie obowiązkowej dziesięciny, z której istotna część (purfamannatíund oraz wszystkie daniny nieprzekraczające równowartości 5 łokci samodziału) miała trafić w ręce gospodarzy dysponujących zbyt małym majątkiem, by samemu ją uiszczać, bądź też zagrożonych niewypłacalnością z powodu ciążącego na nich obowiązku utrzymania wielu osób zależnych, mogło więc być postrzegane przez boendr jako znaczące usprawnienie systemu.

Rozkładając ciężar zapewnienia wiktu dla ómagar na osoby spoza grona gospodarzy, niwelowano ryzyko upadku gorzej sytuowanych gospodarstw. Czyniono to stosunkowo niewielkim kosztem indywidualnym. Beneficjentami takiego rozwiązania byli więc przede wszystkim sami bcendr, zarówno ci mniej zamożni, w największym stopniu zagrożeni niewypłacalnością w związku realizacją wspólnotowych obowiązków, jak i relatywnie bogaci, którzy dzięki wprowadzeniu tak skonstruowanej dziesięciny odsuwali od siebie widmo upadku gospodarstw swoich relatywnie ubogich sąsiadów, destabilizacji lokalnej społeczności, a nawet załamania się hreppr.

Wspólnota interesu opowiadająca się za wprowadzeniem tíund okazuje się więc znacznie szersza niż ogół goðar. W jej skład możemy zaliczyć wolnych gospodarzy bez względu na ich status majątkowy i społeczny. Grono to miało bardzo heterogeniczny charakter, było zróżnicowane nie tylko pod względem wielkości majątku i pozycji społecznej poszczególnych członków, ale i stopnia zainteresowania realizacją wspólnych postulatów oraz możliwościami w zakresie przechwytywania potencjalnych transferów. Ta wewnętrzna dywersyfikacja sprawiała, iż rzeczona wspólnota interesu w niewielkim stopniu miała problem z „gapowiczami”. Jednocześnie ci jej członkowie, którzy mogli oczekiwać szczególnych korzyści w związku z wprowadzeniem dziesięciny - wodzowie dysponujący prywatnymi kościołami - stanowili nieliczne grono, funkcjonujące $w$ ramach systemu korporatywistycznego, ułatwiającego tworzenie grup interesu. Goðar regularnie spotykali się na dorocznym Zgromadzeniu Powszechnym (albingi), w którym udział był obowiązkowy, i dysponowali sformalizowanym sposobem podejmowania zbiorowych decyzji w ramach obrad Zgromadzenia Prawodawczego (lögrétta). Mając zaś poparcie stowarzyszonych z nimi gospodarzy, potrafili wyegzekwować uchwalone przez siebie normy w praktyce. „Niezwykłe posłuszeństwo”, jakie Islandczycy okazali w sprawie wprowadzenia obowiązkowej dziesięciny biskupowi Gizurrowi, mogło więc stanowić wynik zabiegania o realizację dobrze pojmowanego interesu własnego.

45 W.I. Miller, op. cit., s. 249. 


\section{BIBLIOGRAFIA}

\section{Źródła}

Brennu-Njáls saga. Íslenzk fornrit, 12 bindi., útg. E.Ó. S veins s on, Reykjavík 1954.

Eyrbyggja saga. Íslenzk fornrit, 4 bindi., útg. E.Ó. Sveins s on, Reykjavík 1935.

Eyrbyggja saga, transl., introduction and notes by H. Palss on, P. Edwards, London 1989.

Grágás: Lagasafn íslenska pjóðveldisins, útg. G. Karlsson, K. Sveins son, M. Árnason, Reykjavík 1992.

Islandske Annaler indtil 1578, útg. G. Storm, Christiania 1888.

Íslendingabók and Kristnisaga - The Book of Icelanders, and The Story of the Conversion, Viking Society for Northern Research Text Series, vol. XVIII, transl. S. Grønlie, London 2006.

Laws of Early Iceland: Grágás, the Codex Regius of Grágás with Material from Other Manuscripts, vol. I-II, eds. A. Dennis, P. Foote, R. Perkins, Winnipeg 1980.

Njal's Saga, transl., introduction and notes by R. Cook, London 2001.

\section{Artykuły, monografie, prace zbiorowe}

Bagge S., Cross and Scepter: The Rise of the Scandinavian Kingdoms from the Vikings to the Reformation, Princeton 2014.

Becker G.S., A Theory of Competition Among Pressure Groups for Political Influence, „Quarterly Journal of Economics” 1983, vol. 98, no. 3, s. 371-400.

Bentley A.F., The Process of Government, Chicago 1908.

Blanton R., Fargher L., Collective Action in the Formation of Pre-Modern States, New York 2008.

By ock J.L., Viking Age Iceland, London 2001.

Cattaneo G., Reflection on the Hreppar: The Communities of the Inhabitants of Medieval Iceland, „Cahiers de Civilisation Médiévale” 2014, vol. 57, no. 2, s. 113-131.

Eypórs son B., History of the Icelandic Church 1000-1300: Status of Research [w:] Church Centers in Iceland from the 11th to the 13th Century and Their Parallels in Other Countries, ed. H. Porláks son, Reykholt 2005, s. 19-69.

Farber D.A., Frickey P.P., Law and Public Choice: A Critical Introduction, Chicago 1991.

Friedman D.D., Private Creation and Enforcement of Law: A Historical Case, „Journal of Legal Studies" 1979, vol. 8, no. 2, s. 399-415.

Gullbekk S.H., Money and Its Use in the Saga Society: Silver, Coins and Commodity Money [w:] Viking Settlements and Viking Society Papers from the Proceedings of the Sixteenth Viking Congress, ed. S. Sigmund s son, Reykjavik 2011, s. 176-188.

Jóhannesson J., Íslendinga Saga: A History of the Old Icelandic Commonwealth, Winnipeg 1974.

Kjartansson H.S., Thin on the Ground: Legal Evidence of the Availability of Priests in the 12th Century Iceland [w:] Church Centers in Iceland from the 11th to the 13th Century and Their Parallels in Other Countries, ed. H. Porláksson, Reykholt 2005, s. 95-102.

Kristjánss on J., Eddas and Sagas: Iceland's Medieval Literature, Reykjavík 2007.

Latham E., The Group Basis of Politics, Ithaca 1952.

Levi M., Of Rule and Revenue, Berkeley 1989. 
Mawhinney H.B., Theoretical Approaches to Understanding Interest Groups, „Educational Policy" 2001, vol. 15, no. 1, s. 187-214.

Miller W.I., Bloodtaking and Peacemaking: Feud, Law, and Society in Saga Iceland, Chicago 1990.

Nordal G., Ethics and Action in Thirteenth-Century Iceland, Odense 1998.

Olson M., The Logic of Collective Action: Public Goods and the Theory of Groups, Cambridge 1965 .

Runolfsson Solvason B.T., Institutional Evolution in the Icelandic Commonwealth, „Constitutional Political Economy” 1993, vol. 4, no. 1, s. 115-122.

Rutkowski R., ,A ja nazywam się Ari”. O najstarszej kronice islandzkiej i jej autorze [w:] Autor i jego dzieło $w$ wiekach średnich, red. A. Laskowska, M. Sas, Warszawa 2014, s. 63-76.

Sagi islandzkie. Zarys dziejów literatury staronordyckiej, red. J. Morawiec, Ł. Neubauer, Warszawa 2015.

Sigurðss on J.V., Chieftains and Power in the Icelandic Commonwealth, Odense 1999.

Stein-Wilkeshuis M., The Right to Social Welfare in Early Medieval Iceland, ,Journal of Medieval History" 1982, vol. 8, no. 4, s. 343-352.

Stigler G.J., Free Riders and Collective Action: An Appendix to Theories of Economic Regulation, „Bell Journal of Economics and Management Science” 1974, vol. 5, no. 2, s. 359-365.

The Theory of Market Failure: A Critical Examination, ed. T. Cow en, Fairfax 1988.

Tłaczała P., Analiza grup interesu [w:] Teoria wyboru publicznego. Wstep do ekonomicznej analizy polityki i funkcjonowania sfery publicznej, red. J. Wilkin, Warszawa 2005, s. 184-203.

Truman D., The Governmental Process, New York 1958.

Tullock G., The Economics of Special Privilege and Rent Seeking, New York 1989.

Vesteins son O., The Christianization of Iceland: Priests, Power, and Social Change 1000 1300, Oxford 2000. 